\title{
Antibiotic therapy of choice for community-acquired pneumonia in Malaysian Hajj pilgrims: the pattern and associated factors
}

\section{Antybiotykoterapia jako preferowana metoda leczenia pozaszpitalnego zapalenia płuc u malezyjskich pielgrzymów do Mekki - wzorzec i powiązane czynniki}

\author{
Diana Dzaraly¹, Nor Iza A. Rahman², Mainul Haque ${ }^{3}$, Mohd Suhaimi Bin Ab Wahab4, Nordin Bin Simbak5 \\ Aniza Abd Aziz' ${ }^{6}$ Salwani Ismail², Abdul Razak Abdul Muttalif \\ ${ }^{1}$ Faculty of Medicine, University Sultan Zainal Abidin, Terengganu, Malaysia \\ Head of the Faculty: Nordin Bin Simbak \\ ${ }^{2}$ Unit of Microbiology, Faculty of Medicine, University Sultan Zainal Abidin, Terengganu, Malaysia \\ Head of the Unit: Dr. Nor Iza A. Rahman \\ ${ }^{3}$ Unit of Pharmacology, Faculty of Medicine and Defence Health, National Defence University of Malaysia, Kuala Lumpur, Malaysia \\ Head of the Unit: Kamisha Jurina \\ ${ }^{4}$ USM-KLE International Medical Programme, Belgaum, Karnataka, India \\ Head of the Faculty: Prof. Shaiful Bahari Ismail \\ ${ }^{5}$ University Sultan Zainal Abidin (UniSZA), Terengganu Darul Iman, Malaysia \\ Head of the University: Prof. Dato' Dr. Ahmad Zubaidi bin Abdul Latif \\ ${ }^{6}$ Unit of the Community Medicine, Faculty of Medicine, University Sultan Zainal Abidin, Terengganu, Malaysia \\ Head of the Unit: Dr Aniza Abd Aziz \\ 'Department of Respiratory Medicine, Institute of Respiratory Medicine, Hospital Kuala Lumpur, Kuala Lumpur, Malaysia \\ Head of the Department: Dr. Ashari Bin Yunus
}

Key words: Hajj, pilgrims, community-acquired pneumonia, antibiotic therapy.

Słowa kluczowe: hadżdż, pielgrzymi, pozaszpitalne zapalenie płuc, antybiotykoterapia.

\begin{abstract}
Introduction: Pneumonia is a potentially life-threatening illness that poses global health teething troubles particularly among elderly population and performing Hajj. Empirical antibiotic treatment has been recommended for all suspected community-acquired pneumonia (CAP) patients as initial treatment on admission.

Aim of the research: To describe the antibiotic therapy of CAP and determine the associated factors related to the treatment options among Malaysian Hajj pilgrims.

Material and methods: This was a cross-sectional study involving 91 patients who were admitted to Tabung Haji Hospital, Makkah in 2012, with the clinical diagnosis of pneumonia during Hajj season. The antibiotic treatment for the patients as well as demographic factors and co-morbidity, which potentially influence the treatment options, were studied.

Results: The mean age of the hajj pilgrims was $71.4 \pm 8.7$ years. The most frequently prescribed antibiotic was levofloxacin (44.0\%), followed by azithromycin (40.7\%), cefuroxime (23.1\%), ampicillin + sulbactam (16.5\%), and amoxicillin + clavulanate (15.4\%). The age of patients was significantly associated with levofloxacin, azithromycin, and meropenem $(p=0.032,0.028$, and 0.026 , respectively). Patients with diabetes were statistically significantly highly prescribed with cefuroxime $(p=0.036)$. Conclusions: Levofloxacin and azithromycin were classified as the most common antibiotic treatment given to Malaysian Hajj pilgrim with CAP and their choice was associated with older age of patients. Otherwise, cefuroxime was the prescription of choice in diabetics.
\end{abstract}

\section{Streszczenie}

Wprowadzenie: Zapalenie płuc to choroba zagrażająca życiu, która stanowi poważny problem zdrowotny na świecie, szczególnie wśród osób starszych odbywających pielgrzymkę do Mekki - hadżdż. Antybiotykoterapia empiryczna jest wskazana $\mathrm{u}$ wszystkich chorych z podejrzeniem pozaszpitalnego zapalenia płuc (PZP) jako leczenie początkowe przy przyjęciu.

Cel pracy: Opis antybiotykoterapii w przypadku PZP oraz określenie czynników związanych z możliwościami leczenia u malezyjskich pielgrzymów do Mekki.

Materiał i metody: Przeprowadzono przekrojowe badanie obejmujące 91 chorych przyjętych do szpitala Tabung Haji, Makkah w 2012 r. z diagnozą kliniczną zapalenia płuc w okresie hadżdż. Przedmiotem badania była antybiotykoterapia stosowana u chorych oraz czynniki demograficzne i choroby współistniejące, które mają potencjalny wpływ na możliwości leczenia. 
Wyniki: Średnia wieku pielgrzymów wynosiła 71,4 $\pm 8,7$ roku. Najczęściej przepisywanym antybiotykiem była lewofloksacyna $(44,0 \%)$, a następnie azytromycyna $(40,7 \%)$, cefuroksym $(23,1 \%)$, ampicylina + sulbaktam $(16,5 \%)$, oraz amoksycylina + kwas klawulanowy $(15,4 \%)$. Zaobserwowano istotny związek między wiekiem chorych i lewofloksacyną, azytromycyną i meropenemem (odpowiednio $p=0,032,0,028$ i 0,026). Lekiem istotnie częściej przepisywanym chorym na cukrzycę był cefuroksym $(p=0,036)$.

Wnioski: Lewofloksacyna i azytromycyna zostały sklasyfikowane jako najpopularniejsza antybiotykoterapia stosowana u pielgrzymów z Malezji chorych na PZP i wybór ten był związany ze starszym wiekiem. U chorych na cukrzycę lekiem $\mathrm{z}$ wyboru był cefuroksym.

\section{Introduction}

Hajj is the largest annual Muslim mass gathering for religious and rituals performances, which takes place in Mecca, Kingdom of Saudi Arabia (KSA). Every year, more than 2.5 million Muslims from different parts of the world perform Hajj [1-3]. The Haj] is performed in the month of Dhu Al-Hijjah, which is the twelfth and final month of the Islamic calendar [4]. The gathering of Hajj pilgrims from different countries around the world for a short period of time with unavoidably overcrowded and confined conditions causes public health challenges [5]. Pneumonia is a common and potentially life-threatening illness, which is categorised as one of the major global health problems, particularly among elderly people who perform Hajj [6]. Among infectious diseases, communityacquired pneumonia (CAP) caused by Streptococcus pneumonia is one of the most common diseases addressed by clinicians [7]. It was considered as a major source of morbidity and mortality throughout the world. Basically, mortality can be improved by planning early initiation of antibiotics where the causative organisms are susceptible and adversely affected by inappropriate initial therapy [8].

The empirical antibiotic treatment has been recommended for all suspected CAP as an initial treatment based on pathogen prevalence and local antibiotic resistance profiles [9]. Basically, antibiotics should be promptly taken within $4 \mathrm{~h}$ after admission and persistently for a total of 7-10 days based on the severity of CAP. If there is an improvement of clinical manifestation in patients, they should be treated with oral medication from previous parental antibiotics [10] Multiple scientific societies have created proper guidelines for the empirical use of antimicrobial agents for the initial treatment of CAP, which focused on identification of various pathogens and clinical manifestation of patients [11-14]. The American guideline and the Canadian guideline can be categorized as most preferred guidelines. As these guidelines described treatment plan in accordance to the scientific reasoning and determine any differences between clinical results regarding the length of admitted in the hospital, mortality, and the cost $[14,15]$.

Multiple studies have reported that following guidelines promotes prudent and rational use of not only antibiotics, but also overall medication [16-22]. Special care should be taken regarding antimicrobial resistance, which is a global public health problem [23-28].

The guidelines also recommended the benefit of certain antibiotics for CAP treatment especially in patients who require hospitalisation which listed as second- and third-generation cephalosporins or $\beta$-lactam including $\beta$-lactamase inhibitors and in combination with macrolide [15]. Although S. pneumonia remains the most likely bacterial cause of CAP, it is uncommon and difficult to recognise the specific pathogen in any clinical setting. Uncertainty about the causative bacterium and its antimicrobial susceptibility pattern were categorised as factor contributes to the use of an empiric broad-spectrum antibiotic such as thirdgeneration cephalosporin $[29,30]$. This research is intended to study the type of antibiotic treatment by analysing the antibiotic treatment prescribed by the physician during the Hajj season. The results could be beneficial in the planning and design of the appropriate antibiotic treatment guidelines in the pilgrim community.

\section{Aim of the research}

Thus, specifically, the objective of this study was to describe the pattern of antibiotic treatment in CAP and determine the associated factors related to the treatment options in Malaysian Hajj pilgrims.

\section{Material and methods \\ Study design and patient population}

The method was performed based on an observational cross-sectional study on Hajj Malaysian pilgrims (age $\geq 40$ years) who were admitted to Tabung Haji (TH) hospital in Makkah or Madinah presenting with the sign and symptoms of pneumonia. The study was conducted during Hajj season in October $2012(1433 \mathrm{H})$. A total of 91 patients with clinical diagnosis of pneumonia were included as participants in this study.

\section{Study procedure}

The clinically suspected Hajj pilgrims with pneumonia, who fulfilled the criteria for admission, were admitted to TH hospital. The patients who were later assessed and confirmed with the clinical diagnosis of pneumonia by the physicians were included in the 
study. The clinical diagnosis was made based on clinical manifestations as well as chest radiograph findings of the patient. The demographic data, past medical history, pneumococcal vaccination status, clinical manifestations, investigations, and management of the patients were recorded into a case record form. Antibiotic therapy is the main highlight in this study, so the details of antibiotic treatment were recorded as well. A suspected pneumonia patient admitted to TH hospital with or without the presence or without underlying disease was classified as an inclusion criterion.

\section{Statistical analysis}

The Statistical Package for the Social Sciences (SPSS) version 20.0 was used for data entry and statistical analyses. Descriptive statistics were applied to assess the baseline characteristics of who was admitted to TH Hospital. The independent $t$-test was used to compare the means of a numerical variable between two independent variables. The $\chi^{2}$ test was carried out to observe the association between two categorical variables. Fisher's exact test was performed to observe the association between two categorical variables from a small sample size. A $p$-value $<0.05$ was considered to be statistically significant.

\section{Ethical approval}

Official ethical approval was obtained from the Ministry of Health Research and Ethics Committee
Malaysia (MREC), with reference number NMRR14-1177-21761 (IIR). During Hajj season, a suspected pneumonia Hajj pilgrim who was admitted to TH hospital and met the inclusion and exclusion criteria was selected as an eligible respondent. A consent form was distributed to them as participation proof.

\section{Results}

\section{Sociodemographic characteristics}

A total of 91 respondents with the diagnosis of clinical pneumonia were recruited for this study. Baseline demographic and clinical characteristics of the patient are summarised in Table 1. Males appeared to be affected more compared to females $(58.2 \%$ and $41.8 \%$, respectively), with a mean age of $71.4 \pm 8.7$ years. The most common clinical presentation of pneumonia among Hajj pilgrims was cough (87.9\%), followed by fever (82.4\%) and breathlessness (52.7\%). Redgarding underlying disease, more than half of the patients were hypertensive $(57.1 \%$ ), while $26.4 \%$ of patients had chronic obstructive pulmonary disease (COPD), followed by diabetes $(23.1 \%)$ and asthma $(12.1 \%)$. Overall, only $17.6 \%$ of the pilgrims were vaccinated with pneumococcal vaccine (PPSV23).

\section{Pattern of antibiotic therapy}

The pattern of antibiotic therapy for Malaysian Hajj pilgrims who were admitted for pneumonia is

Table 1. Baseline characteristic of patients $(n=91)$

\begin{tabular}{|c|c|c|c|}
\hline Characteristic & Frequency & Percentage (\%) & Mean (SD) \\
\hline \multicolumn{4}{|l|}{ Gender: } \\
\hline Male & 53 & 58.2 & \\
\hline Female & 38 & 41.8 & \\
\hline Age & & & $71.4(8.7)$ \\
\hline \multicolumn{4}{|c|}{ Pneumococcal vaccines status: } \\
\hline Taken Pneumo 23 & 16 & 17.6 & \\
\hline Not taken & 75 & 82.4 & \\
\hline \multicolumn{4}{|l|}{ Symptomsa: } \\
\hline Fever & 75 & 82.4 & \\
\hline Cough & 80 & 87.9 & \\
\hline Breathlessness & 48 & 52.7 & \\
\hline \multicolumn{4}{|l|}{ Underlying disease $\mathrm{e}^{\mathrm{b}}$ : } \\
\hline Hypertension & 52 & 57.1 & \\
\hline COPD & 24 & 26.4 & \\
\hline Diabetes & 21 & 23.1 & \\
\hline Asthma & 11 & 12.1 & \\
\hline
\end{tabular}

apatients may experience more than one symptom. ${ }^{b}$ Patients may experience more than one underlying disease. 
Table 2. Pattern of antibiotic therapy among Hajj pilgrims $(n=91)$

\begin{tabular}{|lc|}
\hline Pattern of antibiotic treatment & Percentage (\%) \\
Meropenem & 1.1 \\
Ciprofloxacin & 2.2 \\
Ceftriaxone & 2.2 \\
Erythromycin ethylsuccinate (EES) & 3.3 \\
Cefepime & 4.0 \\
Amoxicillin + clavulanate & 15.4 \\
Ampicillin + sulbactam & 16.5 \\
Cefuroxime & 23.1 \\
Azithromycin & 40.7 \\
Levofloxacin & 44.0 \\
\hline
\end{tabular}

shown in Table 2 . The pattern of antibiotic therapy prescribed was influenced by the severity of pneumonia, the presence of co-morbidities, as well as clinical risk factors. Based on our study, the most frequently prescribed antibiotic was levofloxacin (44.0\%), followed by azithromycin $(40.7 \%)$, cefuroxime $(23.1 \%)$, ampicillin + sulbactam (16.5\%), and amoxicillin + clavulanate (15.4\%). Meropenem (1.1\%), ceftriaxone (2.2\%), ciprofloxacin $(2.2 \%)$, erythromycin ethyl-succinate (3.3\%), and cefepime (4.4\%) were the least prescribed.

\section{Antibiotic therapy result vs. age, gender, and underlying illness}

This study revealed that the age of the patient had a significant influence on the choice of antibiotic therapy of levofloxacin, azithromycin, and meropenem ( $p=0.032,0.028,0.026$, respectively) among pneumonia patients (Table 3 ). However, there was no significant association between the choices of antibiotic prescribed with gender (Table 3). Although the other underlying diseases (COPD, hypertension, diabetes, asthma) did not influence the choice of most of antibiotic treatment for Malaysia Hajj pilgrims with pneumonia, patients with diabetes were statistically significantly highly prescribed with cefuroxime ( $p=0.036$ ) (Table 4$)$. Table 3 also shows the mean age of pilgrims according to their antibiotic therapy. The mean age of subjects in this study was $71.4 \pm 8.7$ years. The mean age over 65 years old was related to prescriptions of certain antibiotics such as meropenem (52 \pm 0$)$, ciprofloxacin (77.5 $\pm 3.5)$, ceftriaxone $(80 \pm 1.4)$, EES $(68.7 \pm 3.2)$, cefepime (75.8 \pm 8.9$)$, ampicillin + sulbactam (72.1 \pm 7.3$)$, amoxicillin + clavulanate $(70.7 \pm 8)$, cefuroxime $(68.2 \pm 11.2)$, azithromycin (68.9 \pm 9.3$)$, and levofloxacin (73.5 \pm 7.3$)$.

\section{Discussion}

The present findings can be considered as the most recent evidence to discuss the factors which influence the antibiotic prescription of choice in pneumonia patient during Hajj. This study was supported by a few standard antibiotic treatment guidelines, which stated that well-planned antibiotic therapy could reduce the mortality rate of CAP in hospitalised patients. These outcomes could be used to improve the antibiotic guidelines for treating pneumonia among Malaysian Hajj pilgrims.

The previous study on clinical and temporal patterns of severe pneumonia causing critical illness in Hajj pilgrims showed that the mean \pm SD age was $64 \pm 12$ years [31]. In contrast, the mean age of Malaysian Hajj pilgrims who developed pneumonia during Hajj $1433 \mathrm{H}$ season was $71.4 \pm 8.7$ years. Most Malaysian Hajj pilgrims were in the elderly age group. In general, elderly pilgrims were susceptible to infection due to decreased immune response and aggravation by other factors such as exertion, lack of sleep, and disturbances in their dietary schedule [32]. A cough $(87.9 \%)$ was the most common symptom reported by Malaysian Hajj pilgrims, followed by fever (82.4\%) and breathlessness (52.7\%). This study was in concordance with a study which revealed that cough episodes were categorised as common complaints with a very high attack rate during pilgrimage [33]. This study has revealed that the number of pneumonia cases in males $(58.2 \%)$ was slightly higher compared to females $(41.8 \%)$. This finding was similar to the previous study where pneumonia affected males more than females $(56.6 \%$ and $43.4 \%$, respectively) [5]. Most women or elderly pilgrims will assign or delegate men pilgrims during ramī aj-jamarāt (the Stoning of the Devil) ritual performance. This could be one of the factors for the higher proportion of males suffering compared to females [34].

Eradication of the infecting organism with the resolution of clinical disease can be defined as the main goal of antibiotic therapy [35]. Causative pathogens and their antibiotic susceptibility were categorised as specific criteria for appropriate drug selection [35]. Even though more accurate and advance rapid diagnostic methods were available, most patients received empirical antibiotic as an initial treatment [36, 37]. A respiratory fluoroquinolone (which should be used alone for a penicillin-allergic patient) and $\beta$-lactam plus a macrolide (preferred $\beta$-lactam agent includes cefotaxime, ceftriaxone, ampicillin, and ertapenem for selected patients; with doxycycline) plus azithromycin were classified as recommended regimen for hospital treatment [6]. The specific selection of empirical antibiotic therapy should be based on certain guidelines such as risk stratification of the patient; severity of pneumonia (based on physical findings, chest X-ray, and laboratory assessments), elderly patient, presence of co-morbidities and existence of identified clinical risk factor for drug-resistant or unidentified pathogen and; resistance pattern of local 
Table 3. Antibiotic therapy association with age and gender

\begin{tabular}{|c|c|c|c|c|c|}
\hline \multirow[t]{2}{*}{ Antibiotic therapy } & \multicolumn{2}{|c|}{ Age } & \multicolumn{3}{|c|}{ Gender, $n(\%)$} \\
\hline & Mean (SD) & $P$-value ${ }^{a}$ & Male & Female & $P$-value ${ }^{b}$ \\
\hline Ampicillin + sulbactam*: & & 0.715 & & & 0.733 \\
\hline Yes & $72.1(7.3)$ & & $8(15.8)$ & $7(18.4)$ & \\
\hline No & $71.2(9.1)$ & & $43(84.3)$ & 31 (81.6) & \\
\hline Amoxicillin + clavulanate*: & & 0.791 & & & 0.989 \\
\hline Yes & $70.7(8.0)$ & & $8(15.7)$ & $6(15.8)$ & \\
\hline No & $71.5(9.0)$ & & $43(84.3)$ & $32(84.2)$ & \\
\hline Ciprofloxacin*: & & 0.323 & & & 0.505 \\
\hline Yes & $77.5(3.5)$ & & $2(3.9)$ & $0(0)$ & \\
\hline No & $71.2(8.9)$ & & $49(96.1)$ & $38(100)$ & \\
\hline Cefuroxime*: & & 0.154 & & & 0.986 \\
\hline Yes & $68.2(11.2)$ & & $12(23.5)$ & $9(23.7)$ & \\
\hline No & $72.3(7.9)$ & & 39 (79.6) & $29(76.3)$ & \\
\hline Ceftriaxone*: & & 0.163 & & & 0.180 \\
\hline Yes & $80(1.4)$ & & $0(0)$ & $2(5.3)$ & \\
\hline No & $71.2(8.8)$ & & $1(100)$ & $36(94.7)$ & \\
\hline Cefepime*: & & 0.436 & & & 0.309 \\
\hline Yes & $75.8(8.9)$ & & $1(2)$ & $3(7.9)$ & \\
\hline No & $71.2(8.9)$ & & $50(98)$ & $35(92.1)$ & \\
\hline Levofloxacin*: & & 0.032 & & & 0.642 \\
\hline Yes & $73.5(7.3)$ & & $24(47.1)$ & $16(42.1)$ & \\
\hline No & $69.5(9.7)$ & & $27(52.9)$ & $22(57.9)$ & \\
\hline Azithromycin*: & & 0.028 & & & 0.338 \\
\hline Yes & $68.9(9.3)$ & & $19(37.3)$ & $8(47.4)$ & \\
\hline No & $73.1(8.1)$ & & $32(62.7)$ & $20(52.6)$ & \\
\hline Erythromycin ethylsuccinate $(E E S)^{\star}$ : & & 0.592 & & & 0.0573 \\
\hline Yes & $68.7(3.2)$ & & $1(2.0)$ & $2(5.3)$ & \\
\hline No & $71.5(9.0)$ & & $50(98)$ & $36(94.7)$ & \\
\hline Meropenem*: & & 0.026 & & & 1.0 \\
\hline Yes & $52(0)$ & & $1(2.0)$ & $0(0)$ & \\
\hline No & $71.6(8.6)$ & & $50(98)$ & $38(100)$ & \\
\hline
\end{tabular}

${ }^{*}$ Patient may be prescribed with more than one type of antibiotic, ${ }^{a}$ Independent $t$ test; $p<0.05=$ significant, ${ }^{b} \chi^{2}$ test; $p<0.05=$ significant.

epidemiology [38, 39]. In addition, patients who were admitted to hospital because of CAP should be treated with antibiotic therapy within a timeline of 4 to $8 \mathrm{~h}$ after arrival. Antibiotic treatment delayed for more than $4 \mathrm{~h}$ will enhance the mortality rate [40].

Hospitalised patients were basically prescribed empirically with more than one type of antibiotics based on the patient's condition [25, 26, 35]. Empirically given antimicrobials also should be based on guidelines [35]. In this study, the finding revealed that azithromycin and levofloxacin were the most frequently prescribed antibiotics among Malaysian Hajj pilgrims. Levofloxacin can be defined as a broadspectrum antibiotic of the fluoroquinolone drug class and the levo-isomer of its predecessor ofloxacin [41]. Levofloxacin plays an important role in professional medical society guidelines for the treatment of pneumonia, urinary tract infection, and abdominal infections, especially in Gram-positive and Gram-negative bacterial pathogens $[2,24,42]$. It is also recommended 


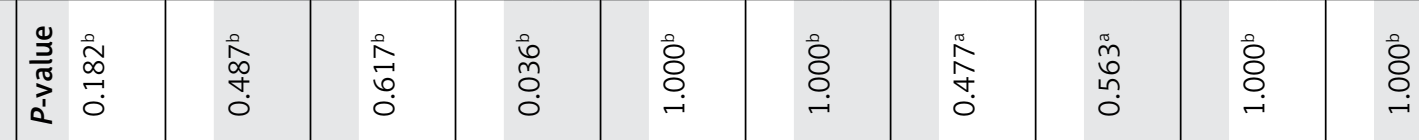

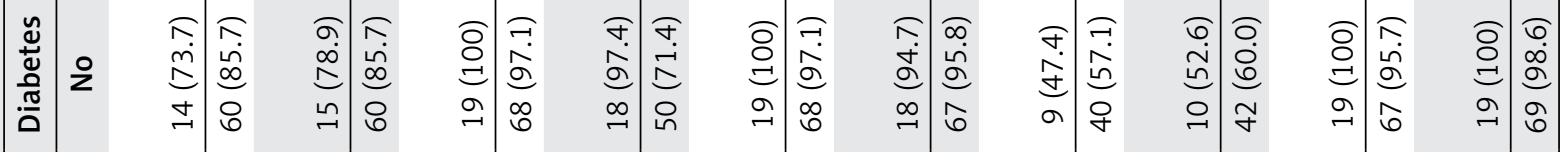

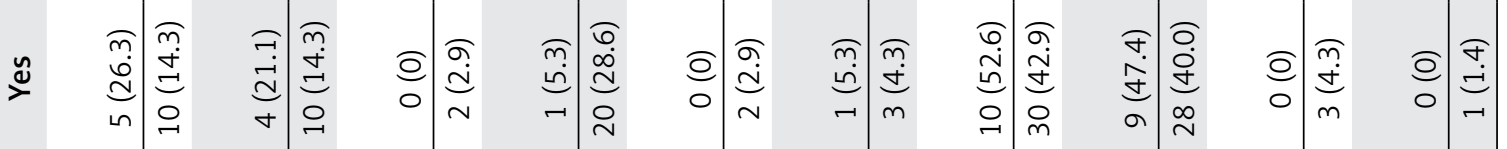

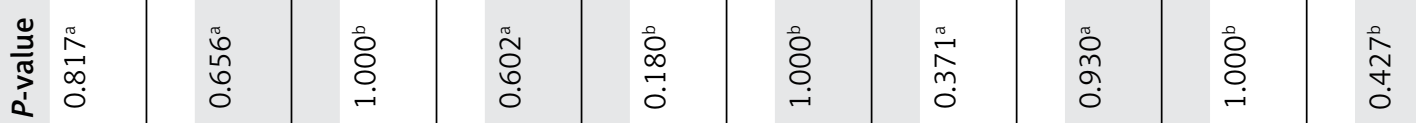
ᄃ

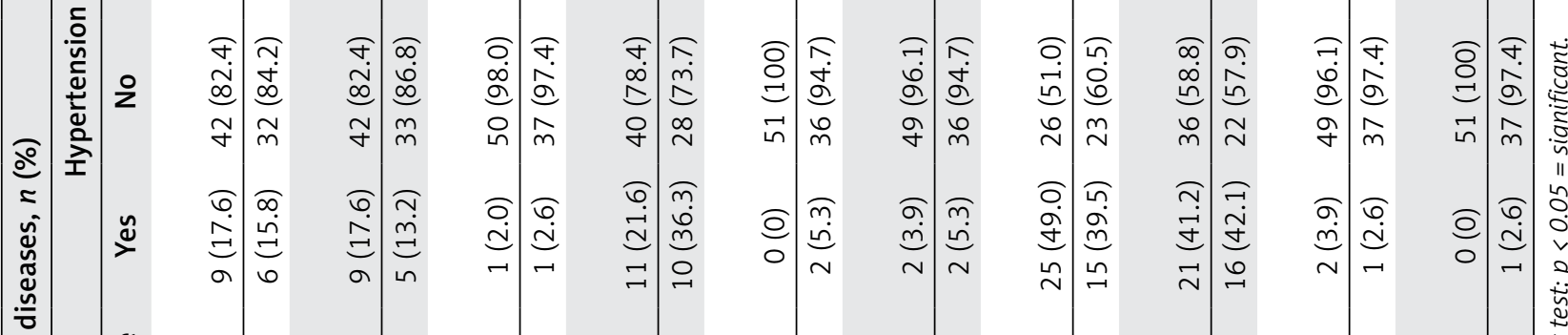

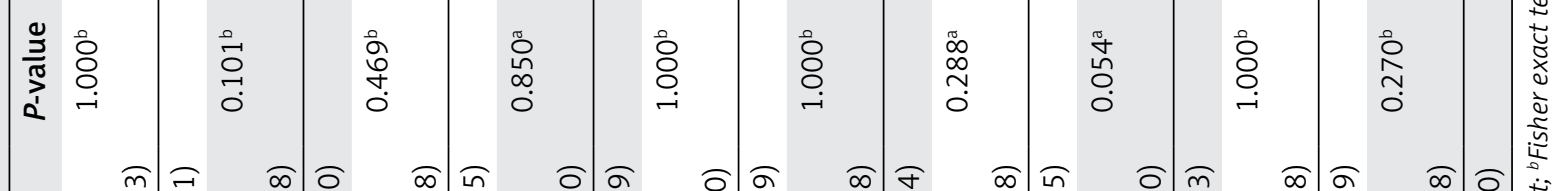

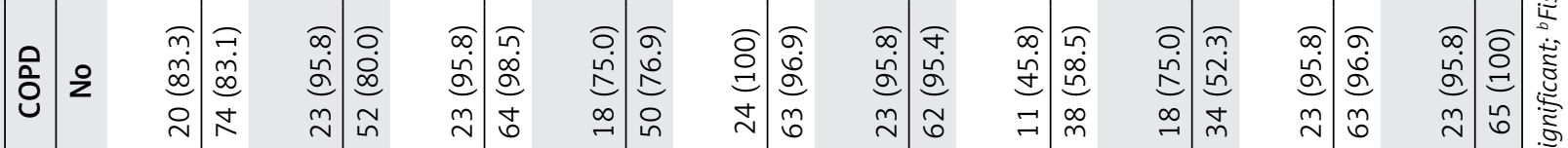

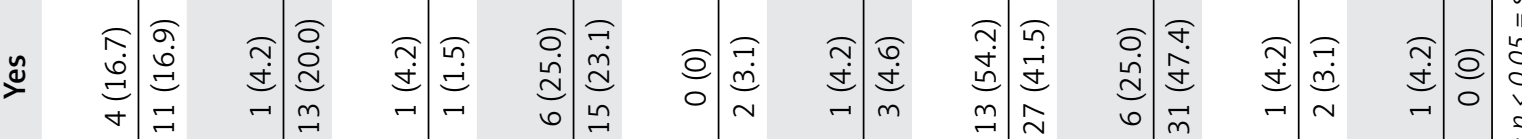

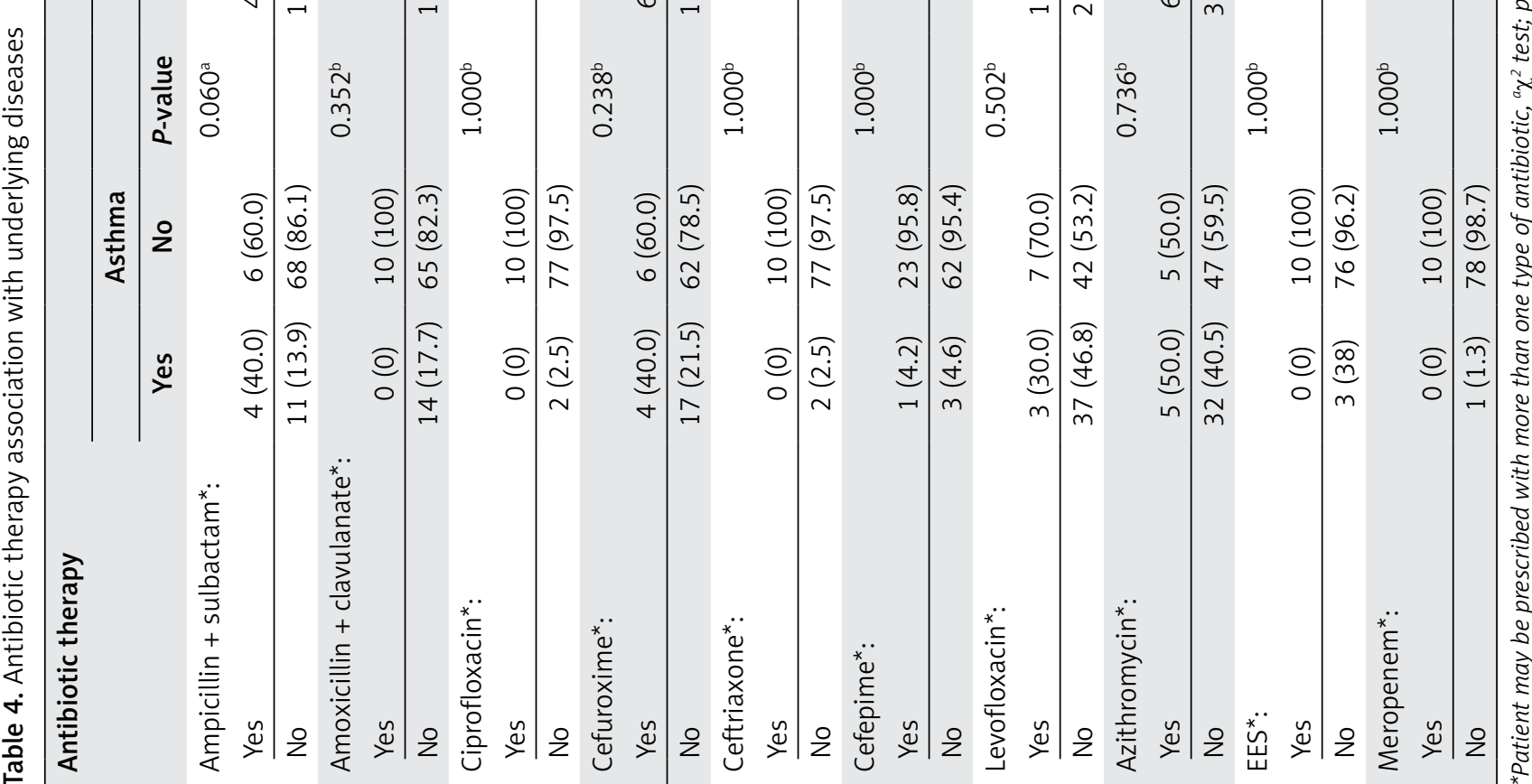


as the first-line treatment for CAP patients together with the presence of co-morbidities such as heart, lung, or liver diseases [6]. Azithromycin is a useful antibiotic for the treatment of bacterial infection (specific in CAP), which is widely used alone or in combination with other medicine [43].

This study also revealed a significant association between age and antibiotic therapy prescribed for levofloxacin, azithromycin, and meropenem among pilgrims. The old medical guideline has revealed that the outcome for elderly patients (age over 65 years with comorbidities) with CAP may improve when a macrolide agent (azithromycin, erythromycin, or clarithromycin) is combined with a second- or third-generation cephalosporin $[44,45]$. High frequency of atypical pathogens causing mixed pneumonia might be categorised as a key success of the macrolide agent [46]. The study also highlighted levofloxacin as the most common antibiotic treatment given to Malaysian Hajj pilgrims with CAP, and their choice was influenced by the elderly patient. This is also supported by the previous finding where fluoroquinolone agents (such as levofloxacin, sparfloxacin, grepafloxacin, or other fluoroquinolones (with enhanced pneumococcal activity) were classified as part of the initial management strategy for either outpatient pneumonia (alone) or inpatient pneumonia (preferably as combination antimicrobials), especially in elderly patients [47].

Meropenem also illustrated a significant influence on the choice of antibiotic therapy in this study. This is in parallel with another distinct finding where the association of the safety profile of meropenem in persons aged 65 years old and above has been discussed with the presence of renal impairment. The study also compared the use of meropenem with other antimicrobial treatment in a patient with bacterial infection [48]. Meropenem can be considered the less commonly prescribed medicine in this study, in which the patients were prescribed more often with azithromycin and levofloxacin. Although it has been reported that carbapenems were $100 \%$ sensitive to the isolates of bacteria from sputum samples of diabetic patients with CAP [49], indiscriminate use of carbapenems will also promote the non-rational use of antimicrobials and finally increase antimicrobial resistance at the cost of health [50-52]. Resistance to antibiotics results in an enormous increase of the costs for not only for the hospital, society, and patients' personal expenses, but also public health care costs to overcome resistance. There will be a need to use more expensive proprietary brand drugs, more diagnostic tests, with prolonged hospital stay and sick leave, or even death [53]. Therefore, the current study results show limited carbapenem use can be considered as prudent use of antimicrobials.

This study has several limitations. First, the study focused on antibiotic therapy alone, without discuss- ing the duration of treatment, which limits the scope of related findings. Second, a lack of supportive findings in current studies, especially during Hajj season, was classified as one of the limitations. The majority of supportive evidence was supported by old findings due to limited new publications regarding that topic. Lastly, the researchers experienced constraints while conduct the study during Hajj season, particularly time limitation and several other factors that could not be avoided. Researchers were permitted to only one hospital and only one month for data collection. This was a very important study limitation.

\section{Conclusions}

The most frequently prescribed antibiotics were among the recommended first-line antibiotics, such as levofloxacin and azithromycin. Others were cefuroxime $(23.1 \%)$, ampicillin + sulbactam (16.5\%), and amoxicillin + clavulanate (15.4\%). However, meropenem $(1.1 \%)$, ceftriaxone $(2.2 \%)$, ciprofloxacin $(2.2 \%)$, erythromycin ethyl succinate (3.3\%), and cefepime $(4.4 \%)$ were less commonly prescribed. Older age in CAP patients was found to have some influence on the antibiotic choice for levofloxacin, azithromycin, and meropenem. Otherwise, cefuroxime was preferred for those with diabetes. A specific antibiotic guideline for pilgrims with CAP could be considered as an effective way of enhancing the effectiveness and good quality of health care during Hajj.

\section{Acknowlegments}

We wish to thank the Director-General of Health, Ministry of Health of Malaysia, and MREC for permission to conduct the study and subsequently the publication of this paper. We are greatly indebted to all staffs of Tabung Haji (TH) Hospital for their support in ensuring the success of this study.

\section{Conflict of interest}

The authors declare no conflict of interest.

\section{References}

1. Ebrahim SH, Memish ZA, Uyeki TM, Khoja TAM, Marano N, McNabb SJN. Pandemic H1N1 and the 2009 Hajj. Science 2009; 326: 938-40.

2. Dzaraly ND, Rahman NIA, Haque M, Simbak NB, Wahab MSA, Aziz AA, Abdulllah MS, Mohamad I, Muttalif ARA, Ismail S, Abdullah S. The characteristics of hospitalized pneumonia patients among Malaysian Hajj Pilgrims. J Young Pharm 2016; 8: 284-90.

3. Dzaraly ND, Rahman NI, Simbak NB, Wahab SA, Osman O, Ismail S, Haque M. Patterns of communicable and noncommunicable diseases in Pilgrims during Hajj. Res J Pharm Tech 2014; 7: 1052-9.

4. Al-Ghamdi SM, Akbar HO, Qari YA, Fathaldin OA, Al-Rashed RS. Pattern of admission to hospitals during Muslim pilgrimage (Hajj). Saudi Med J 2003; 24: 1073-6. 
5. Asghar AH, Ashshi AM, Azhar EI, Bukhari SZ, Zafar TA Momenah AM. Profile of bacterial pneumonia during Hajj. Indian J Med Res 2011; 133: 510-3.

6. Mandell LA, Wunderink RG, Anzueto A, Bartlett JG, Campbell GD, Dean NC, Dowell SF, File TM Jr, Musher DM, Niederman MS, Torres A, Whitney CG. Infectious Diseases Society of America; American Thoracic Society. Infectious Diseases Society of America/American Thoracic Society consensus guidelines on the management of community-acquired pneumonia in adults. Clin Infect Dis 2007; 44: S27-72.

7. File TM. Community-acquired pneumonia. Lancet 2003; 362: 1991-2001.

8. Feldman C, Brink AJ, Richards GA, Maartens G, Bateman ED. Management of community acquired pneumonia in adults. South Afr Med J 2008; 23: 31-42.

9. Lim WS, Baudouin SV, George RC, Hill AT, Jamieson C, Le Juene I, Macfarlane JT, Read RC, Roberts HJ, Levy ML, Wani M, Woodhead MA. Pneumonia Guidelines Committee of the BTS Standards of Care Committee. BTS guidelines for the management of com- munity acquired pneumonia in adults: update 2009. Thorax 2009; 64: iii1-55.

10. Patterson CM, Loebinger MR. Community acquired pneumonia: assessment and treatment. Clin Med (Lond) 2012; 12: 283-6.

11. Bartlett JG, Breiman RF, Mandell LA, File TM Jr. Community-acquired pneumonia in adults: guideline for management. Infectious Diseases Society of America. Clin Infect Dis 1998; 26: 811-38.

12. British Thoracic Society. Guidelines for the management of community-acquired pneumonia in adults admitted to hospital. Brit J Hosp Med 1993; 49: 346-50.

13. Mandell LA, Niederman MS. The Canadian communityacquired pneumonia consensus group. Antimicrobial treatment of community acquired pneumonia in adults: a conference report. Can J Infect Dis 1993; 4: 25-8.

14. Niederman MS, Bass JB Jr, Campell GD, Fein AM, Grossman RF, Mandell LA, Marrie TJ, Sarosi GA, Torres A, $\mathrm{Yu}$ VL. Guidelines for the initial management of adults with community-acquired pneumonia: diagnosis, assessment of severity, and initial antimicrobial therapy. American Thoracic Society. Medical Section of the American Lung Association. Am Rev Respir 1993; 148: 1418-26.

15. Mandell LA, Marrie TJ, Grossman RF, Chow AW, Hyland RH; Canadian Community-acquired Pneumonia Working Group. Canadian guidelines for initial management of community-acquired pneumonia: an evidencebased update by the Canadian Infectious Disease Society and Canadian Thoracic Society. Clin Infect Dis 2000; 31: 383-421.

16. Haque M, Rahman NIA, Zulkifli Z, Ismail S. Antibiotic prescribing and resistance: knowledge level of medical students of clinical years of University Sultan Zainal Abidin, Malaysia. Ther Clin Risk Manag 2016; 12: 413-26.

17. Hoque R, Mostafa A, Haque M. Intern doctors' views on the current and future antibiotic resistance situation of Chattagram Maa O Shishu Hospital Medical College, Bangladesh. Ther Clin Risk Manag 2015; 11: 1177-85.

18. Salam A, Haque M, Islam MZ, Rahman NIA, Helali AM, Muda TFMBT, Yousuf R, Yesmin F, Rahman Z, Alattraqchi AG. Addressing rational prescribers through the pharmacology and therapeutics course work of MBBS syllabus in Bangladesh. Int Res J Pharm 2013; 4: 60-3.
19. Islam MZ, Rahman MF, Mossaddek ASM, Rozario RJ, Iftekhar AFMH, Akhter S, Jahan I, Helali AM, Dali WPEW, Ismail S, Rahman NIA, Haque M. Bangladeshi interns' knowledge of pharmacology and therapeutics for prescribing. J App Pharm Sci 2014; 4: 043-51.

20. Hoque R, Mostafa A, Haque M. Insight of medical students of clinical years to antimicrobials prescribing and resistance in a Private Medical School Chattagram Maa O Shishu Hospital Medical College, Chittagong, Bangladesh. J Young Pharm 2016; 8: 447-55.

21. Llor C, Bjerrum L. Antimicrobial resistance: risk associated with antibiotic overuse and initiatives to reduce the problem. Ther Adv Drug Saf 2014; 5: 229-41.

22. Levy SB. Factors impacting on the problem of antibiotic resistance. J Antimicrob Chemother 2002; 49: 25-30.

23. World Health Organization. Antimicrobial Resistance Global Report on Surveillance. WHO Press, World Health Organization, 20 Avenue Appia, 1211 Geneva 27, Switzerland 2014. Available at: http://apps.who.int/iris/bitstream/10665/112642/1/9789241564748_eng.pdf [Accessed on 6-May-2016].

24. US Department of Health and Human Services. Centers for Disease Control Prevention. Antibiotic Resistance Threats in The United States, 2013. Available at: http:// www.cdc.gov/drugresistance/pdf/ar-threats-2013-508. pdf [Accessed on 6-May-2016].

25. Ventola CL. The antibiotic resistance crisis. Part 1: causes and threats. Pharm Ther 2015; 40: 277-83.

26. O'Neill J. Review on antimicrobial resistance: antimicrobial resistance: tackling a crisis for the health and wealth of nations. London: Wellcome Trust. 2014. Available at: http://amr-review.org/sites/default/files/AMR\%20 Review\%20Paper\%20-\%20Tackling\%20a\%20crisis\%20 for $\% 20$ the $\% 20$ health $\% 20$ and $\% 20$ wealth $\% 20$ of $\% 20$ nations_1.pdf [Accessed on 6-May-2016].

27. Smith RD, Coast J. Antimicrobial resistance: a global response. Bull World Health Organ 2002; 80: 126-33.

28. Bush K, Courvalin P, Dantas G, Davies J, Eisenstein B, Huovinen P, Jacoby GA, Kishony R, Kreiswirth BN, Kutter E, Lerner SA, Levy S, Lewis K, Lomovskaya O, Miller JH, Mobashery S, Piddock LJ, Projan S, Thomas CM, Tomasz A, Tulkens PM, Walsh TR, Watson JD, Witkowski J, Witte W, Wright G, Yeh P, Zgurskaya HI. Tackling antibiotic resistance. Nat Rev Microbiol 2011; 9: 894-6.

29. Ambroggio L, Tabb LP, O'Meara T, Sheffler-Collins S, McGowan KL, Shah SS. Influence of antibiotic susceptibility patterns on empiric antibiotic prescribing for children hospitalized with community-acquired pneumonia. Pediatr Infect Dis J 2012; 31: 331-6.

30. Brogan TV, Hall M, Williams DJ, Neuman MI, Grijalva CG, Farris RWD, Shah SS. Variability in processes of care and outcomes among children hospitalized with community-acquired pneumonia. Pediatr Infect Dis J 2012; 31: 1036-41.

31. Mandourah Y, Al-Radi A, Ocheltree AH, Ocheltree SR, Fowler RA. Clinical and temporal patterns of severe pneumonia causing illness during Hajj. BMC Infect Dis 2012; $12: 117$.

32. Ahmed QA, Arabi YM, Memish ZA. Health risks at the Hajj. Lancet 2006; 367: 1008-15.

33. Gautret P, Soula G, Delmont J, Parola P, Brouqui P. Common health hazards in French pilgrims during the Hajj of 2007. A prospective cohort study. J Travel Med 2009; 16: $377-81$. 
34. Alzahrani AG, Choudhry AJ, Al Mazroa MA, Turkistani AH, Nouman GS, Memish ZA. Pattern of diseases among visitors to Mina health centers during the Hajj season, 1429 H. J Infect Public Health 2012; 5: 22-34.

35. Leekha S, Terrell CL, Edson RS. General principles of antimicrobial therapy. Mayo Clin Proc 2011; 86: 156-67.

36. Anevlavis S, Bouros D. Community acquired bacterial pneumonia. Expert Opin Pharmacother 2010; 11: 361-74.

37. Caliendo AM, Gilbert DN, Ginocchio CC, Hanson KE, May L, Quinn TC, Tenover FC, Alland D, Blaschke AJ, Bonomo RA, Carroll KC, Ferraro MJ, Hirschhorn LR, Joseph WP, Karchmern T, MacIntyre AT, Reller LB, Jackson AF; the Infectious Diseases Society of America (IDSA). Better Tests, Better Care: Improved Diagnostics for Infectious Diseases. Clin Infect Dis 2013; 57: S139-70.

38. Niederman MS, Mandell LA, Anzueto A, Bass JB, Broughton WA, Campbell GD, Dean N, File T, Fine MJ, Gross PA, Martinez F, Marrie TJ, Plouffe JF, Ramirez J, Sarosi GA, Torres A, Wilson R, Yu VL; American Thoracic Society. Guidelines for the management of adults with community-acquired pneumonia. Am J Respir Crit Care Med 2001; 163: 1730-54.

39. Bartlett JG, Dowell SF, Mandell LA, File Jr TM, Musher DM, Fine MJ. Guidelines from the Infectious Diseases Society of America. Practice guidelines for the management of community-acquired pneumonia in adults. Clin Infect Dis 2000; 31: 347-82.

40. Meehan TP, Fine MJ, Krumholz HM, Scinto JD, Galusha DH, Mockalis JT, Weber GF, Petrillo MK, Houck PM, Fine JM. Quality of care, process, and outcomes in elderly patients with pneumonia. JAMA 1997; 278: 2080-4.

41. Nelson JM, Chiller TM, Powers JH, Angulo FJ. Fluoroquinolone-resistant Campylobacter species and the withdrawal of fluoroquinolones from use in poultry: a public health success story. Clin Infect Dis 2007; 44: 977-80.

42. Croom KF, Goa KL. Levofloxacin: a review of its use in the treatment of bacterial infections in the United States. Drugs 2003; 63: 2769-802.

43. Shah PB, Giudice JC, Griesback R Jr, Morley TF, Vasoya A. The newer guidelines for the management of community-acquired pneumonia. J Am Osteopath Assoc 2004; 104: 521-6.

44. Gleason PP, Meehan TP, Fine JM, Galusha DH, Fine MJ. Association between antimicrobial therapy and medical outcomes for hospitalized elderly patients with pneumonia. Arch Intern Med 1999; 159: 2562-72.

45. Stahl JE, Barza M, Desjardin J, Martin R, Eckman MH. Effect of macrolides as part of initial empiric therapy on length of stay in patients hospitalized with communityacquired pneumonia. Arch Intern Med 1999; 159: 2576-80.

46. Macfarlane J, Holmes W, Gard P, Thornhill D, Macfarlane R, Hubbard R. Reducing antibiotic use for acute bronchitis in primary care: blinded, randomized controlled trial of patient information leaflet. BMJ 2002; 324: 91-4.

47. Cassiere HA, Fein A. Duration and route of antibiotic therapy in community acquired pneumonia: switch and step down therapy. Semin Respir Infect 1998; 13: 36-42.

48. Cunha BA. Meropenem in elderly and renally impaired patients. Int J Antimicrob Agents 1998; 10: 107-17.

49. Saibal MAA, Rahman SHZ, Nishat L, Sikder NH, Begum SA, Islam MJ, Uddin KN. Community acquired pneumonia in diabetic and non-diabetic hospitalized pa- tients: presentation, causative pathogens and outcome. Bangladesh Med Res Counc Bull 2012; 38: 98-103.

50. Doi A, Iwata K, Takegawa H, Miki K, Sono Y, Nishioka H, Takeshita J, Tomii K, Haruta T. Community-acquired pneumonia caused by carbapenem-resistant Streptococcus pneumoniae: re-examining its prevention and treatment. Int J Gen Med 2014; 7: 253-7.

51. Gupta N, Limbago BM, Patel JB, Kallen AJ. Carbapenemresistant Enterobacteriaceae: epidemiology and prevention. Clin Infec Dis 2011; 53: 60-7.

52. Hong T, Moland ES, Abdalhamid B, Hanson ND, Wang J, Sloan C, Fabian D, Farajallah A, Levine J, Thomson KS. Escherichia coli: development of carbapenem resistance during therapy. Clin Infec Dis 2005; 40: e84-6.

53. React Facts. Economic Aspects of Antibiotic Resistance. 2008. Available at: http://www.reactgroup.org/uploads/ publications/react-publications/economic-aspects-of-antibiotic-resistance.pdf [Accessed on 12-June-2015].

\section{Address for correspondence}

\section{Prof. Mainul Haque}

Unit of Pharmacology

Faculty of Medicine and Defence Health

Universiti Pertahanan Nasional Malaysia

(National Defence University of Malaysia)

Kem Sungai Besi, 57000 Kuala Lumpur, Malaysia

Phone:+60109265543

E-mail: runurono@gmail.com 